\title{
STUDIES IN OSTEO-ARTHRITIS USING INTRA- ARTICULAR TEMPERATURE RESPONSE TO INJECTION OF HYDROCORTISONE ACETATE AND PREDNISONE
}

BY

\author{
JOSEPH L. HOLLANDER AND ROBERT MOORE \\ From the Arthritis Section, Department of Medicine, Hospital of the University of Pennsylvania, Philadelphia, Pa
}

(RECEIVED FOR PUBLICATION SEPTEMBER 27, 1956)

The use of intra-articular hydrocortisone acetate in the treatment of osteo-arthritis has been shown to produce a temporary improvement of symptoms in many cases (Hollander, Stoner, Brown, and De Moor, 1951), although enthusiasm for this method has been tempered by warnings of the possibility of increasing the damage in joints subjected to excessive use in the periods of freedom from symptoms (Young, Ward, and Henderson, 1954). The results of treatment of the knee have been more encouraging than those of treatment of other joints, presumably because of the ease with which injection of the knee joint can be accomplished.

The present study has been undertaken in a series of patients with osteo-arthritis, to determine what changes occur in the intra-articular temperature, before and after the injection of hydrocortisone acetate or prednisone into the knee joint. An endeavour was also made to correlate these temperature changes with the relief of symptoms in the affected joint.

\section{Materials and Method}

26 cases of osteo-arthritis were studied. All complained of pain, stiffness, swelling, and limitation of movement of varying degree in one or both knees, effusions were present in the joint in twelve cases, and the erythrocyte sedimentation rate was in no case above $36 \mathrm{~mm}$./hr (normal $20 \mathrm{~mm}$./hr-Wintrobe method). The cases were divided into five groups, the particulars of which are contained in Table I (opposite).

Group 1.-A control group of five patients. Three were females suffering from generalized osteo-arthritis (Kellgren and Moore, 1952) and showed the characteristic Heberden nodes, and first carpometacarpal arthritis in addition to arthritis of the knees and other joints. In the other two patients, who were males, the symptoms were localized to the knees. One had been a carpenter for many years his occupation necessitating a great deal of kneeling, while the other had marked bowing of the tibiae following rickets in childhood and this appeared to have thrown a strain on the knees. Whether these constitute cases of osteo-arthritis due to repeated minor trauma remains uncertain, but the knees alone were involved.

All five cases were investigated without injection of a therapeutic substance, and in two cases both knees were examined, making a total of seven joints in the control group. However, two knee joints were injected with the inert aqueous vehicle used for the suspension hydrocortisone acetate.

Group 2.- Sixteen patients suffering from generalized osteo-arthritis. Ten of these were submitted to the whole investigation. One of the female controls also appears in this group. Intra-articular hydrocortisone acetate was administered.

Group 3.-The two male controls. Intra-articular hydrocortisone acetate was administered.

Group 4.-Five patients suffering from osteo-arthritis of the knees which was apparently secondary to the strain of weight-bearing from obesity. Intra-articular hydrocortisone acetate was admiristered.

Group 5.-Three patients suffering from generalized osteo-arthritis. Two of these had previously been used in the Group 2. This series received prednisone intra-articularly.

The knee joint was chosen for intra-articular studies because it is relatively easy of access. All the subjects reclined on a couch, with the legs and feet uncovered from just above the knee, for one hour before the tests, in a room maintained at $25-26^{\circ} \mathrm{C}$. After the skin on the medial aspect of the patella had been sterilized, a 19-gauge needle was inserted into the joint without preliminary local anaesthesia, producing only temporary discomfort during the introduction. Fluid when present was aspirated. A filamentous copper-constantan thermocouple was passed through the needle into the joint, and the electromotive force developed in the 
TABLE I

PARTICULARS OF PATIENTS

\begin{tabular}{|c|c|c|c|c|c|c|c|c|}
\hline Group & Diagnosis & Case No. & Sex & Knee & $\begin{array}{c}\text { Age } \\
\text { (yrs) }\end{array}$ & $\begin{array}{l}\text { Height } \\
\text { (in.) }\end{array}$ & $\begin{array}{l}\text { Weight } \\
\text { (lb.) }\end{array}$ & $\begin{array}{l}\text { Erythrocyte } \\
\text { Sedimenta- } \\
\text { tion Rate } \\
\text { (mm./hr } \\
\text { Wintrobe) }\end{array}$ \\
\hline \multirow{3}{*}{$\begin{array}{c}1 \\
\text { Controls }\end{array}$} & $\begin{array}{l}\text { Generalized } \\
\text { Osteo-Arthritis }\end{array}$ & 1 & $\mathbf{F}$ & $\left\{\begin{array}{l}\mathbf{R} \\
\mathbf{L}\end{array}\right.$ & 77 & 66 & 144 & 28 \\
\hline & & $\frac{2}{3}$ & $\begin{array}{l}\mathbf{F} \\
\mathbf{F}\end{array}$ & $\begin{array}{l}\mathbf{R} \\
\mathbf{R}\end{array}$ & $\begin{array}{l}64 \\
62\end{array}$ & $\begin{array}{l}65 \\
61\end{array}$ & $\begin{array}{l}141 \\
154\end{array}$ & $\begin{array}{l}35 \\
26\end{array}$ \\
\hline & $\begin{array}{l}\text { Traumatic } \\
\text { Arthritis }\end{array}$ & $\begin{array}{l}4 \\
5\end{array}$ & $\begin{array}{l}\mathbf{M} \\
\mathbf{M}\end{array}$ & $\mathbf{L}$ & $\begin{array}{l}61 \\
64\end{array}$ & $\begin{array}{l}65 \\
64\end{array}$ & $\begin{array}{l}167 \\
170\end{array}$ & $\begin{array}{l}15 \\
29\end{array}$ \\
\hline $\begin{array}{c}2 \\
\text { Hydrocortisone } \\
\text { Acetate }\end{array}$ & $\begin{array}{l}\text { Generalized } \\
\text { Osteo-Arthritis }\end{array}$ & $\begin{array}{r}6 \\
7 \\
8 \\
9 \\
10 \\
11 \\
12 \\
13 \\
14 \\
15 \\
16 \\
17 \\
18 \\
19 \\
20\end{array}$ & $\begin{array}{l}F \\
F \\
F \\
F \\
F \\
F \\
F \\
F \\
F \\
F \\
F \\
F \\
F \\
F \\
F\end{array}$ & $\begin{array}{l}\mathbf{L} \\
\mathbf{R} \\
\mathbf{R} \\
\mathbf{L} \\
\mathbf{R} \\
\mathbf{L} \\
\mathbf{L} \\
\mathbf{R} \\
\mathbf{R} \\
\mathbf{L} \\
\mathbf{R} \\
\mathbf{R} \\
\mathbf{L} \\
\mathbf{R} \\
\mathbf{R}\end{array}$ & $\begin{array}{l}67 \\
76 \\
56 \\
57 \\
62 \\
51 \\
67 \\
77 \\
62 \\
69 \\
65 \\
62 \\
51 \\
59 \\
65\end{array}$ & $\begin{array}{l}64 \frac{1}{2} \\
60 \\
62 \\
63 \\
66 \\
62 \frac{1}{2} \\
60 \\
64 \\
60 \\
59 \\
65 \\
66 \frac{1}{2} \\
62 \\
58 \\
63\end{array}$ & $\begin{array}{l}158 \\
148 \\
144 \\
148 \\
170 \\
163 \\
133 \\
165 \\
140 \\
111 \\
134 \\
170 \\
160 \\
126 \\
172\end{array}$ & $\begin{array}{l}20 \\
24 \\
19 \\
22 \\
14 \\
20 \\
24 \\
18 \\
26 \\
30 \\
26 \\
14 \\
22 \\
29 \\
36\end{array}$ \\
\hline $\begin{array}{c}3 \\
\text { Hydrocortisone } \\
\text { Acetate }\end{array}$ & $\begin{array}{c}\text { Traumatic } \\
\text { Arthritis }\end{array}$ & $\begin{array}{l}4 \\
5\end{array}$ & $\begin{array}{l}\mathbf{M} \\
\mathbf{M}\end{array}$ & $\begin{array}{l}\mathbf{R} \\
\mathbf{R}\end{array}$ & $\begin{array}{l}61 \\
64\end{array}$ & $\begin{array}{l}65 \\
64\end{array}$ & $\begin{array}{l}167 \\
170\end{array}$ & $\begin{array}{l}15 \\
29\end{array}$ \\
\hline $\begin{array}{c}4 \\
\text { Hydrocortisone } \\
\text { Acetate }\end{array}$ & $\begin{array}{l}\text { Obesity with } \\
\text { Osteo-Arthritis }\end{array}$ & $\begin{array}{l}21 \\
22 \\
23 \\
24 \\
25\end{array}$ & $\begin{array}{l}\mathbf{F} \\
\mathbf{F} \\
\mathbf{F} \\
\mathbf{F} \\
\mathbf{F}\end{array}$ & $\begin{array}{l}\mathbf{L} \\
\mathbf{L} \\
\mathbf{L} \\
\mathbf{R} \\
\mathbf{R}\end{array}$ & $\begin{array}{l}63 \\
67 \\
56 \\
49 \\
54\end{array}$ & $\begin{array}{l}61 \\
64 \\
60 \\
60 \\
61\end{array}$ & $\begin{array}{l}167 \\
184 \\
180 \\
176 \\
184\end{array}$ & $\begin{array}{l}24 \\
36 \\
35 \\
25 \\
20\end{array}$ \\
\hline$\stackrel{5}{\text { Prednisone }}$ & $\begin{array}{l}\text { Generalized } \\
\text { Osteo-Arthritis }\end{array}$ & $\begin{array}{r}7 \\
14 \\
26\end{array}$ & $\begin{array}{l}\mathbf{F} \\
\mathbf{F}\end{array}$ & $\begin{array}{l}\mathbf{R} \\
\mathbf{R} \\
\mathbf{L}\end{array}$ & $\begin{array}{l}76 \\
62 \\
68\end{array}$ & $\begin{array}{l}60 \\
60 \\
60\end{array}$ & $\begin{array}{l}148 \\
140 \\
179\end{array}$ & $\begin{array}{l}24 \\
26 \\
30\end{array}$ \\
\hline
\end{tabular}

thermocouple was measured by a Brown Automaticrecording Potentiometer, the result being expressed in ${ }^{\circ} \mathrm{C}$. and recorded directly on a moving chart. Readings from the intra-articular lead were recorded at intervals of one and a half minutes. When the temperature record had become stationary, usually in 45 minutes, the lead was disconnected from the patient and hydrocortisone acetate $37.5 \mathrm{mg}$. in $1.5 \mathrm{ml}$. solution, or prednisone $15 \mathrm{mg}$. in $1.5 \mathrm{ml}$. solution, was injected into the joint through the needle. The appearance of the synovial fluid was noted, its viscosity roughly tested by the drop technique (Hollander, 1953), and its mucin clot formation with dilute acetic acid examined. A cell count was done using undiluted fluid, and a smear made for differential counts. The studies were repeated at the end of 24 hours, and 48 hours, and then after 5 days. Only one injection of hydrocortisone acetate or prednisone was given in each study.

\section{Controls}

\section{Results}

The preliminary intra-articular temperature for the group fell within the range of 31.5 to $36^{\circ} \mathrm{C}$. (Fig. 1; and Table II, overleaf). It rose in four knee joints in the first 24 hours, the maximum rise being

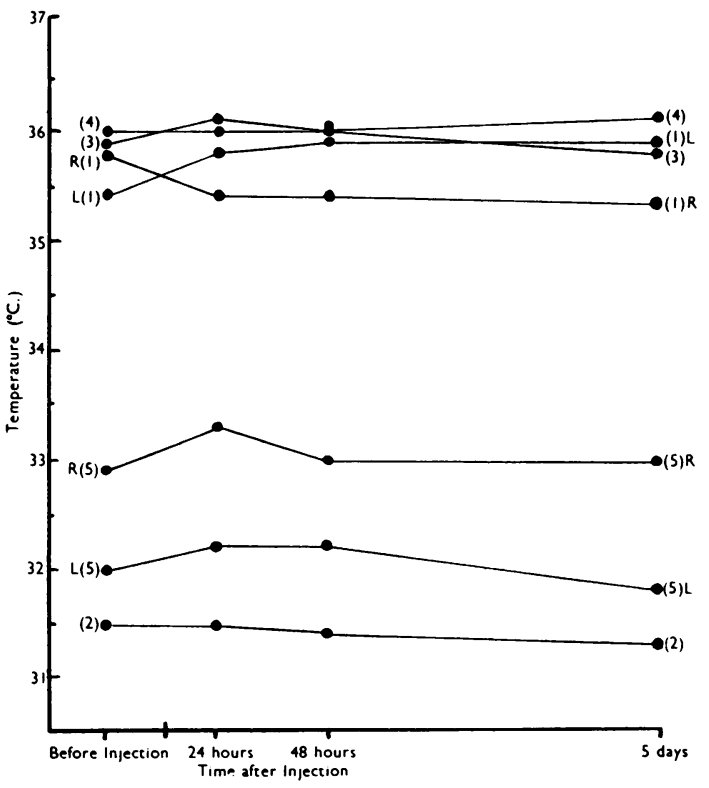

Fig. 1.-Intra-articular temperature changes in controls. 
INTRA-ARTICULAR TEMPERATURE ( $\left.{ }^{\circ} \mathrm{C}.\right)$

\begin{tabular}{|c|c|c|c|c|c|c|}
\hline \multirow{2}{*}{ Group } & \multirow{2}{*}{ Case No. } & \multirow{2}{*}{ Knee } & \multirow{2}{*}{ Before } & \multicolumn{3}{|c|}{ After } \\
\hline & & & & 24 hrs & $48 \mathrm{hrs}$ & 5 days \\
\hline $\begin{array}{c}1 \\
\text { Controls }\end{array}$ & $\begin{array}{l}1 \\
2 \\
3 \\
4 \\
5\end{array}$ & $\begin{array}{c}\left\{\begin{array}{l}\mathbf{R} \\
\mathbf{L}\end{array}\right. \\
\mathbf{R} \\
\mathbf{R} \\
\mathbf{L}\end{array}$ & $\begin{array}{l}35 \cdot 8 \\
35.4 \\
31 \cdot 5 \\
35.9 \\
36.0 \\
32.9 \\
32.0\end{array}$ & $\begin{array}{l}35 \cdot 4 \\
35 \cdot 8 \\
31 \cdot 5 \\
36 \cdot 1 \\
36 \cdot 0 \\
33 \cdot 3 \\
32 \cdot 2\end{array}$ & $\begin{array}{l}35 \cdot 4 \\
35 \cdot 9 \\
31 \cdot 4 \\
36 \cdot 0 \\
36 \cdot 0 \\
33 \cdot 0 \\
32 \cdot 2\end{array}$ & $\begin{array}{l}35 \cdot 3 \\
35 \cdot 9 \\
31 \cdot 3 \\
35 \cdot 8 \\
36 \cdot 1 \\
33 \cdot 0 \\
31 \cdot 8\end{array}$ \\
\hline$\stackrel{2}{\text { Hydrocortisone Acetate }}$ & $\begin{array}{r}1 \\
6 \\
7 \\
8 \\
9 \\
10 \\
11 \\
12 \\
13 \\
14\end{array}$ & $\begin{array}{l}\mathbf{L} \\
\mathbf{L} \\
\mathbf{R} \\
\mathbf{R} \\
\mathbf{L} \\
\mathbf{R} \\
\mathbf{L} \\
\mathbf{L} \\
\mathbf{R} \\
\mathbf{R}\end{array}$ & $\begin{array}{l}35 \cdot 8 \\
34 \cdot 3 \\
35 \cdot 4 \\
35 \cdot 0 \\
33 \cdot 6 \\
34 \cdot 4 \\
34 \cdot 4 \\
35 \cdot 8 \\
35 \cdot 0 \\
35 \cdot 4\end{array}$ & $\begin{array}{l}36 \cdot 3 \\
34 \cdot 8 \\
35 \cdot 5 \\
35 \cdot 6 \\
34 \cdot 5 \\
35 \cdot 9 \\
34 \cdot 7 \\
36 \cdot 3 \\
35 \cdot 6 \\
36 \cdot 2\end{array}$ & $\begin{array}{l}36 \cdot 2 \\
33 \cdot 4 \\
35 \cdot 9 \\
34 \cdot 6 \\
35 \cdot 2 \\
36 \cdot 4 \\
34 \cdot 9 \\
36 \cdot 3 \\
35 \cdot 5 \\
35 \cdot 6\end{array}$ & $\begin{array}{l}35 \cdot 9 \\
32 \cdot 2 \\
35 \cdot 3 \\
34 \cdot 6 \\
34 \cdot 8 \\
36 \cdot 1 \\
34 \cdot 7 \\
35 \cdot 8 \\
34 \cdot 6 \\
35 \cdot 1\end{array}$ \\
\hline$\stackrel{3}{\text { Hydrocortisone Acetate }}$ & $\begin{array}{l}4 \\
5\end{array}$ & $\begin{array}{l}\mathbf{R} \\
\mathbf{R}\end{array}$ & $\begin{array}{l}35 \cdot 4 \\
33 \cdot 2\end{array}$ & $\begin{array}{l}35 \cdot 8 \\
34 \cdot 2\end{array}$ & $\begin{array}{l}36 \cdot 3 \\
34 \cdot 2\end{array}$ & $\begin{array}{l}36 \cdot 2 \\
33 \cdot 8\end{array}$ \\
\hline Hydrocortisone Acetate & $\begin{array}{l}21 \\
22 \\
23 \\
24 \\
25\end{array}$ & $\begin{array}{l}\mathbf{L} \\
\mathbf{L} \\
\mathbf{L} \\
\mathbf{R} \\
\mathbf{R}\end{array}$ & $\begin{array}{l}35 \cdot 9 \\
36 \cdot 3 \\
35 \cdot 8 \\
36 \cdot 3 \\
36 \cdot 3\end{array}$ & $\begin{array}{l}35 \cdot 8 \\
36 \cdot 4 \\
35 \cdot 8 \\
36 \cdot 2 \\
36 \cdot 2\end{array}$ & $\begin{array}{l}35 \cdot 3 \\
36 \cdot 4 \\
35 \cdot 2 \\
36 \cdot 1 \\
36 \cdot 3\end{array}$ & $\begin{array}{l}35 \cdot 4 \\
36 \cdot 0 \\
35 \cdot 2 \\
35 \cdot 8 \\
36 \cdot 4\end{array}$ \\
\hline $\begin{array}{c}5 \\
\text { Prednisone }\end{array}$ & $\begin{array}{r}7 \\
14 \\
26\end{array}$ & $\begin{array}{l}\mathbf{R} \\
\mathbf{R} \\
\mathbf{L}\end{array}$ & $\begin{array}{l}35 \cdot 5 \\
35 \cdot 4 \\
33 \cdot 0\end{array}$ & $\begin{array}{l}35 \cdot 8 \\
36 \cdot 0 \\
33 \cdot 9\end{array}$ & $\begin{array}{l}35 \cdot 3 \\
36 \cdot 0 \\
35 \cdot 0\end{array}$ & $\begin{array}{l}35 \cdot 0 \\
36 \cdot 0 \\
34 \cdot 5\end{array}$ \\
\hline
\end{tabular}

$0.4 \mathrm{C}$.; in two knees it remained unchanged; in the remaining knee it fell by $0.4 \mathrm{C}$. In the cases showing fluctuations in the first 24 hours, there was a gradual return of the temperature towards the original level by the end of the fifth day. The most marked changes of intra-articular temperature occurred in the two cases receiving the inert aqueous vehicle.

Synovial fluid was obtained throughout the investigation from one knee joint of each control case, and included fluid from the two knees which had been injected with the inert aqueous vehicle. In every case it was clear and yellowish, and showed the high viscosity characteristic of osteo-arthritis (Ropes and Bauer, 1953). No obvious clinical change occurred in the viscosity of the fluid throughout the investigation. The highest initial white cell count was 1,060 per c.mm., the cells being predominantly mononuclear (Table III). It rose slightly in four cases in the first 24 hours, and had fallen towards or below the original level by the end of the fifth day. The highest rise did not occur in either of the cases which had received the inert aqueous vehicle and had undergone the maximum fluctuations of intra-articular temperature. In one case, which had shown no fluctuations in temperature in the first 24 hours, the white cell count actually fell slightly. The symptoms of stiffness after rest and pain in the knees were present in all the control patients. These symptoms were relieved
TABLE III

SYNOVIAL FLUID CELL COUNTS

\begin{tabular}{|c|c|c|c|c|c|c|}
\hline \multirow{2}{*}{ Group } & \multirow{2}{*}{$\begin{array}{l}\text { Case } \\
\text { No. }\end{array}$} & \multirow{2}{*}{ Knee } & \multirow{2}{*}{ Before } & \multicolumn{3}{|c|}{ After } \\
\hline & & & & $24 \mathrm{hrs}$ & $48 \mathrm{hrs}$ & 5 days \\
\hline 1 & $\begin{array}{l}1^{*} \\
2 \\
3 \\
4 \\
5^{*}\end{array}$ & $\begin{array}{l}\mathbf{R} \\
\mathbf{R} \\
\mathbf{R} \\
\mathbf{L} \\
\mathbf{R}\end{array}$ & $\begin{array}{r}595 \\
325 \\
285 \\
1,060 \\
485\end{array}$ & $\begin{array}{r}670 \\
290 \\
370 \\
1,665 \\
505\end{array}$ & $\begin{array}{l}545 \\
490 \\
295 \\
110 \\
250\end{array}$ & $\begin{array}{r}995 \\
470 \\
260 \\
40 \\
150\end{array}$ \\
\hline 2 & $\begin{array}{r}8 \\
9 \\
10\end{array}$ & $\begin{array}{l}\mathbf{R} \\
\mathbf{L} \\
\mathbf{R}\end{array}$ & $\begin{array}{l}375 \\
405 \\
505\end{array}$ & $\begin{array}{r}3,490 \\
2,765 \\
685\end{array}$ & $\begin{array}{r}1,720 \\
1,280 \\
190\end{array}$ & $\begin{array}{l}150 \\
310 \\
150\end{array}$ \\
\hline 3 & 5 & $\mathbf{R}$ & 360 & 685 & 570 & 100 \\
\hline 4 & $\begin{array}{l}24 \\
25\end{array}$ & $\begin{array}{l}\mathbf{R} \\
\mathbf{R}\end{array}$ & $\begin{array}{r}1,125 \\
85\end{array}$ & $\begin{array}{l}1,170 \\
2,245\end{array}$ & $\begin{array}{r}1,530 \\
720\end{array}$ & $\begin{array}{r}1,060 \\
190\end{array}$ \\
\hline 5 & 26 & $\mathbf{L}$ & 115 & 20 & 170 & 160 \\
\hline
\end{tabular}

* Inert aqueous vehicle.

in four patients, but relapsed completely by the fourth day (Table IV, opposite). In the two cases given the inert aqueous vehicle the same degree of relief $\mathcal{N}$ appeared to occur in the knee which had been in- N jected with the inert aqueous vehicle as in the N opposite knee which had received no injection. In ${ }_{0}$ all cases the relief was noticed within 24 hours of the introduction of the needle for the preliminary test. In one case no change in symptoms occurred throughout the investigation. 
TABLE IV

RELIEF OF SYMPTOMS

\begin{tabular}{|c|c|c|c|c|c|c|}
\hline \multirow{2}{*}{ Group } & \multirow{2}{*}{ Case No. } & \multirow{2}{*}{ Knee } & \multicolumn{2}{|c|}{ Stiffness } & \multicolumn{2}{|c|}{ Pain } \\
\hline & & & Relief & $\begin{array}{l}\text { Duration } \\
\text { (days) }\end{array}$ & Relief & $\begin{array}{c}\text { Duration } \\
\text { (days) }\end{array}$ \\
\hline$\stackrel{1}{\text { Controls }}$ & $\begin{array}{l}1 \\
2 \\
3 \\
4 \\
5\end{array}$ & $\begin{array}{l}\left\{\begin{array}{l}\mathbf{R} \\
\mathbf{L}\end{array}\right. \\
\mathbf{R} \\
\mathbf{R} \\
\mathbf{L} \\
\left\{\begin{array}{l}\mathbf{R} \\
\mathbf{L}\end{array}\right.\end{array}$ & $\begin{array}{r}\text { Partial } \\
\text { Partial } \\
\text { Partial } \\
\text { Nil } \\
\text { Partial } \\
\text { Partial } \\
\text { Partial }\end{array}$ & $\begin{array}{l}4 \\
4 \\
3 \\
\\
4 \\
3 \\
3\end{array}$ & $\begin{array}{r}\text { Partial } \\
\text { Partial } \\
\text { Partial } \\
\text { Nil } \\
\text { Partial } \\
\text { Partial } \\
\text { Partial }\end{array}$ & $\begin{array}{l}4 \\
4 \\
3 \\
\\
4 \\
3 \\
3\end{array}$ \\
\hline$\stackrel{2}{\text { Hydrocortisone Acetate }}$ & $\begin{array}{r}1 \\
6 \\
7 \\
8 \\
9 \\
10 \\
11 \\
12 \\
13 \\
14 \\
15 \\
16 \\
17 \\
18 \\
19 \\
20\end{array}$ & $\begin{array}{l}\mathbf{L} \\
\mathbf{L} \\
\mathbf{R} \\
\mathbf{R} \\
\mathbf{L} \\
\mathbf{R} \\
\mathbf{L} \\
\mathbf{L} \\
\mathbf{R} \\
\mathbf{R} \\
\mathbf{L} \\
\mathbf{R} \\
\mathbf{R} \\
\mathbf{L} \\
\mathbf{R} \\
\mathbf{R}\end{array}$ & $\begin{array}{l}\text { Complete } \\
\text { Complete } \\
\text { Complete } \\
\text { Complete } \\
\text { Complete } \\
\text { Complete } \\
\text { Nil } \\
\text { Complete } \\
\text { Complete } \\
\text { Nil } \\
\text { Partial } \\
\text { Partial } \\
\text { Complete } \\
\text { Partial } \\
\text { Complete } \\
\text { Complete }\end{array}$ & $\begin{array}{r}10 \\
90 \\
14 \\
9 \\
7 \\
21 \\
\\
14 \\
21 \\
\\
10 \\
7 \\
21 \\
10 \\
10 \\
7\end{array}$ & $\begin{array}{l}\text { Partial } \\
\text { Complete } \\
\text { Nil } \\
\text { Complete } \\
\text { Complete } \\
\text { Complete } \\
\text { Nil } \\
\text { Complete } \\
\text { Complete } \\
\text { Nil } \\
\text { Partial } \\
\text { Nil } \\
\text { Complete } \\
\text { Nil } \\
\text { Complete } \\
\text { Complete }\end{array}$ & $\begin{array}{r}7 \\
90 \\
9 \\
7 \\
28 \\
7 \\
21 \\
10 \\
\\
21 \\
14 \\
7\end{array}$ \\
\hline$\stackrel{3}{\text { Hydrocortisone Acetate }}$ & $\begin{array}{l}4 \\
5\end{array}$ & $\begin{array}{l}\mathbf{R} \\
\mathbf{R}\end{array}$ & $\begin{array}{l}\text { Complete } \\
\text { Partial }\end{array}$ & $\begin{array}{l}10 \\
10\end{array}$ & $\begin{array}{l}\text { Complete } \\
\text { Partial }\end{array}$ & $\begin{array}{r}7 \\
10\end{array}$ \\
\hline$\stackrel{4}{4}$ Hydrocortisone Acetate & $\begin{array}{l}21 \\
22 \\
23 \\
24 \\
25\end{array}$ & $\begin{array}{l}\mathbf{L} \\
\mathbf{L} \\
\mathbf{L} \\
\mathbf{R} \\
\mathbf{R}\end{array}$ & $\begin{array}{l}\text { Partial } \\
\text { Complete } \\
\text { Complete } \\
\text { Partial } \\
\text { Complete }\end{array}$ & $\begin{array}{r}21 \\
7 \\
10 \\
14 \\
28\end{array}$ & $\begin{array}{l}\text { Partial } \\
\text { Complete } \\
\text { Complete } \\
\text { Complete } \\
\text { Complete }\end{array}$ & $\begin{array}{r}21 \\
7 \\
7 \\
21 \\
28\end{array}$ \\
\hline$\stackrel{5}{\text { Prednisone }}$ & $\begin{array}{r}7 \\
14 \\
26\end{array}$ & $\begin{array}{l}\mathbf{R} \\
\mathbf{R} \\
\mathbf{L}\end{array}$ & $\begin{array}{l}\text { Complete } \\
\text { Partial } \\
\text { Complete }\end{array}$ & $\begin{array}{r}7 \\
7 \\
14\end{array}$ & $\begin{array}{l}\text { Partial } \\
\text { Partial } \\
\text { Partial }\end{array}$ & $\begin{array}{r}7 \\
7 \\
14\end{array}$ \\
\hline
\end{tabular}

After Intra-Articular Injection of Hydrocortisone Acetate and Prednisone

The intra-articular temperature in the patients in all the groups studied was above $33^{\circ} \mathrm{C}$., which is the upper limit for normal joints (Horvath and Hollander, 1949; Penneys and Smukler, 1956).

After the injection of hydrocortisone acetate (Fig. 2A, B, overleaf; Table II), the patients with generalized osteo-arthritis and the two males showed a rise in intra-articular temperature which varied from 0.5 to $2 \cdot 1^{\circ} \mathrm{C}$., the maximum rise occurring at the end of 24 hours but being delayed in three cases until the end of 48 hours. In ten of the sixteen patients with generalized osteo-arthritis who were followed for 5 days, the temperature had returned to the pre-injection level or below in seven, while in three it had not quite reached the pre-treatment level by that time.

In the Group 4 patients suffering from obesity (Fig. 2B, overleaf; Table II) there was no significant rise in the intra-articular temperature, and in two of these cases there was a significant fall of temperature below the pre-treatment level by the end of 48 hours. In all cases there was a tendency for the intra- articular temperature to return to or near the pretreatment level.

Three cases of generalized osteo-arthritis which received injections of prednisone responded in a similar manner to those receiving hydrocortisone acetate, but in one case the intra-articular temperature had not begun to return to its original level by the fifth day (Table II).

Synovial fluid was obtained from three cases of generalized osteo-arthritis, one of the male patients, two of the cases suffering from obesity associated with arthritis, and from one of those receiving prednisone (Table III). As in the controls the fluid was clear, highly viscous, and produced a firm clot on addition of acetic acid. In four of the cases which had received hydrocortisone acetate, the white cell count rose significantly by the end of 24 hours, and these included one case where the intraarticular temperature had not changed throughout the investigation; in two other cases minor rises occurred. In five cases the cell count fell to or below the original level, as in the controls, while in one case it rose further by the end of 48 hours before falling below the pre-injection level. The fluid had 


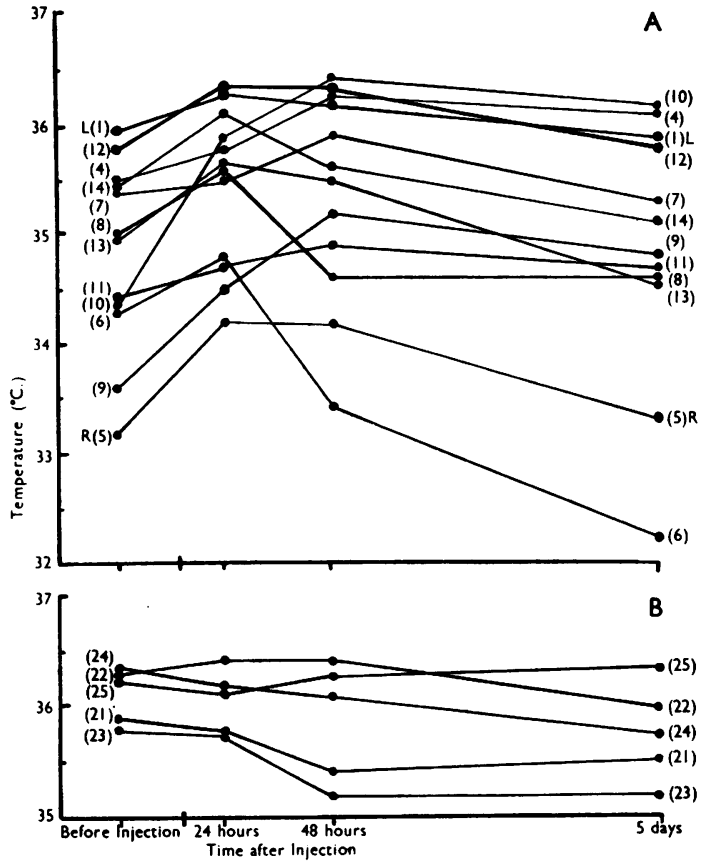

Fig. 2A.-Intra-articular temperature changes in Groups 2 and 3 before and after injection of hydrocortisone acetate.

Fig. 2B.-Intra-articular temperature changes in Group 4 before and after injection of hydrocortisone acetate.

in each case been aspirated as completely as possible on each occasion, and the ratio of polymorphonuclear cells to mononuclear cells remained below 25 per cent. throughout the investigation, suggesting that the rise in count affected in each case both types of cell. In the case which received the prednisone the count actually fell in 24 hours to rise again by the end of 48 hours. The significance of this finding is not known.

The response of the symptoms of stiffness and pain to injection of the knee with hydrocortisone acetate or prednisone is shown in Table IV. In 24 cases there was a definite improvement in, or disappearance of, stiffness; complete relief occurred in seventeen cases, partial relief in seven, and no change in two. Pain completely disappeared in fourteen patients, partially disappeared in seven, and remained unchanged in five (Table IV). The degree of relief of stiffness and pain experienced by an individual patient was not always the same, because in three cases stiffness in the knee was completely relieved, while pain was only partially relieved, and in one case stiffness was completely relieved while pain persisted unchanged. The shortest period of improvement of either symptom was 7 days from the commencement of the investigation and the longest period was 21 days, except in one case in which relief continued for 3 months.

\section{Discussion}

The observation that the intra-articular temperature is above normal in cases of osteo-arthritis is $\overline{0}$ similar to that made by other investigators (Horvath and Hollander, 1949; Fletcher, Jacobs and Rose, $\frac{\bar{\Phi}}{\square}$ 1954).

The significant post-injection rise of intraarticular temperature by the end of 24 hours in $\rightarrow$ thirteen of sixteen cases of osteo-arthritis and in the $\vec{\circ}$ two male cases, and the rise by the end of 48 hours $\overrightarrow{\vec{\omega}}$ in the three remaining cases of generalized osteo- $\omega$ arthritis, contrasts with the temperature changes which occurred in the group presenting with? arthritis of the knees secondary to longstanding $\vec{r}$ obesity. This seems to indicate that in the latter $\vec{\omega}$ group the knee joint reacts differently to hydro- N cortisone acetate. The temperature changes also 0 contrast sharply with those occurring in rheumatoid joints after the injection of intra-articular hydrocortisone acetate when a marked reduction in $\mathbb{R}$ temperature consistently occurs (Hollander and others, 1951). It appears that the temperature changes occurring in the knee joint in response to hydrocortisone depend on the type of joint coros dition present.

Irritation of the joint by the needle could possib produce the rise in temperature found in generalized osteo-arthritis and in the two males, but the fluctuations were greater than those found in the control series and in the obesity groups, indicating that this cannot be the whole explanation. In a series of cases to which intra-articular procaine was administered a similar conclusion was reached (Fletcher and others, 1954).

Transient inflammatory response to the hydrocortisone might conceivably be responsible for the fluctuations in intra-articular temperature, but the clinical condition of the joints never deteriorated, and in most cases the symptoms improved, the $\stackrel{8}{\circ}$ viscosity of the fluid did not change clinically, and the white cell count, although it rose in a number of $ᄋ$ cases, was always predominantly mononuclear and was never found in the range associated with septic arthritis or rheumatoid arthritis.

That vascular changes in the intra-articular $\mathscr{N}$ structures of the knee accompany changes in joint $N$ temperature is suggested by the observation that, in normal individuals, body-heating regularly causes 0 a rise in joint temperature accompanying the rise in skin temperature (Penneys and Smukler, 1956), and plethysmographic studies have also suggested that $\stackrel{\odot}{\rightarrow}$ the blood flow in the normal knee joint changes 
rapidly as the intra-articular temperature rises from 30 to $40^{\circ} \mathrm{C}$. (Bonney, Hughes, and Janus, 1952). Pathological investigations of the osteo-arthritic hip have indicated that the vascular pattern in the bone is increased (Harrison, Schajowicz, and Trueta, 1953), suggesting that changes in blood flow are possible in the joint structures in this condition. It may be, therefore, that the changes in joint temperature indicate changes in joint blood flow, but the ultimate proof of this would depend on other methods of study such as plethysmography. In any event, the mechanism of action of hydrocortisone in generalized osteo-arthritis cannot be the simple anti-inflammatory mechanism that has been shown to operate in rheumatoid arthritis (Hollander and others, 1951).

The synovial fluid viscosity and mucin clot formation remained clinically unchanged throughout the investigation, and the white cell counts were well within the limits usually found in osteoarthritis. That the white cell count rose in four of five controls in the first 24 hours, as well as in the cases receiving hydrocortisone acetate, suggests that a mechanical factor was responsible. Because the proportion of polymorphonuclear cells to monocytes in the fluids remained the same, the changing cell counts may simply be related to the re-accumulation of fluid after complete aspiration of the joints.

Of the two symptoms, stiffness and pain, which troubled the patients, stiffness was more consistently relieved than pain, although in the majority of cases relief was approximately of the same duration for each symptom. It had been hoped to find a relationship between alleviation of these symptoms and changes in the intra-articular temperature accompanying injection of either hydrocortisone acetate or prednisone. However, the response of each symptom to the introduction of the needle into the knee joint was influenced by the knowledge that a special procedure was being used, even in the control group, and although relief was of considerably shorter duration in the controls than in the other groups the observation points again to the care which must be exercised in assessing results of any treatment on a purely symptomatic basis.

This study shows that significant changes in intraarticular temperature occur in the knee joints of patients with generalized osteo-arthritis, and that alterations in the symptoms are not entirely dependent on these changes.

\section{Summary}

A study has been made in 26 cases of osteoarthritis of the response to intra-articular injections of hydrocortisone acetate and prednisone into the knee joint.

The cases were divided into one group of controls, and three groups of patients with generalized osteoarthritis, traumatic arthritis, and obesity associated with arthritis. Joint temperature studies were carried out before and after the intra-articular injections.

The results indicate that the initial joint temperature is higher in these cases than in normal subjects and that it rises after intra-articular injections in some of the groups but not in others; this suggests a difference in the response of the joints to therapy, and contrasts with the changes which occur in the joints of patients with rheumatoid arthritis in similar circumstances.

The relief of the symptoms of pain and stiffness in the joints does not appear to be directly related to the intra-articular temperature changes.

\section{REFERENCES}

Bonney, G. L. W., Hughes, R. A., and Janus, O. (1952). Clin. Sci. $11,167$.

Fletcher, E., Jacobs, J. H., and Rose, C. F. (1954). Ann. phys. Med., $2,123$.

Harrison, M. H. M., Schajowicz, F., and Trueta, J. (1953). J. Bone Jt Surg., 35B, 598.

Hollander, J. L. (1953). "Comroe's Arthritis", 5th ed. Lea and Febiger, Philadelphia.

Stoner, E. K., Brown, E. M., and De Moor, P. (1951). J. clin. Invest., 30, 701 .

Horvath, S. M., and Hollander, J. L. (1949). Ibid., 28, 469.

Horvath, S. M., and Hollander, J. L. (1949). Ibid., 28, 469.
Kellgren, J. H., and Moore, R. (1952). Brit. med. J., 1, 181.

Penneys, R., and Smukler, N. M. (1956). Annals of the Rheumatic Diseases, 15, 241. Ropes, M. W., and Bauer, W. (1953). "Synovial Fluid Changes in Young, H. H., Ward, L. E., and Henderson, E. D. (1954). J. Bone Jt Surg., 36A, 605.

Etude de l'ostéo-arthrite à l'aide de la réponse thermique intra-articulaire à l'injection d'acétate d'hydrocortisone et de prednisone

\section{RÉSUMÉ}

On étudia dans 26 cas d'ostéo-arthrite la réponse à des injections d'acétate d'hydrocortisone et de prednisone dans l'articulation du genou.

Les cas furent divisés en un groupe témoin et trois groupes de malades atteints d'ostéo-arthrite généralisée, d'arthrite traumatique et d'obésité associée à l'arthrite. La température articulaire fut déterminée avant et après les injections intra-articulaires.

Les résultats montrent que la température initiale de l'articulation est plus élevée dans ces cas que chez des sujets normaux, et qu'elle s'élève après les injections intra-articulaires dans certains des groupes mais pas dans d'autres; ceci suggère une différence dans la réponse des articulations au traitement, et contraste avec les altérations qui se produisent dans les articulations de malades atteints d'arthrite rhumatismale dans des circonstances semblables.

Le soulagement des symptômes de douleur et de raideur articulaires ne semble pas être en relation directe avec les variations de la température intraarticulaire. 
Estudio de la osteo-artritis con la ayuda de la respuesta térmica intra-articular á inyecciones de acetato de hidrocortisona y de prednisona.

\section{Sumario}

En 26 cases de osteo-artritis se estudió la respuesta á inyecciones de acetato de hidrocortisona y de prednisona en la articulación de la rodilla.

Los casos fueron repartidos entre un grupo de control y tres grupos de enfermos con osteo-artritis generalizada, artritis traumática y obesidad asociada a la artritis. La temperatura articular fué medida antes y después de las inyecciones intra-articulares.

Los resultados muestran que la temperatura inicial de la articulación es mayor en estos casos que en sujetos normales, aumentando después de las inyecciones intraarticulares en ciertos grupos, pero no en otros; esto sugiere una diferencia en la respuesta de las articulaciones al tratamiento, y contrasta con las alteraciones que se producen en las articulaciones de enfermos con artritis reumatoide en circunstancias semejantes.

El alivio sintomático del dolor y de la rigidez articulares no parece relacionarse directamente con las variaciones de la temperatura intra-articular. 